Review

\title{
Gene-gene and gene-environment interactions: new insights into the prevention, detection and management of coronary artery disease Matthew B Lanktree and Robert A Hegele
}

Address: Departments of Medicine and Biochemistry, Blackburn Cardiovascular Genetics Laboratory, Robarts Research Institute, University of Western Ontario, London, Ontario N6A 5K8, Canada.

Correspondence: Robert A Hegele. Email: hegele@robarts.ca

Published: 26 February 2009

Genome Medicine 2009, 1:28 (doi:10.1 186/gm28)

The electronic version of this article is the complete one and can be

found online at http://genomemedicine.com/content/I/2/28

(C) 2009 BioMed Central Ltd

\begin{abstract}
Despite the recent success of genome-wide association studies (GWASs) in identifying loci consistently associated with coronary artery disease (CAD), a large proportion of the genetic components of CAD and its metabolic risk factors, including plasma lipids, type 2 diabetes and body mass index, remain unattributed. Gene-gene and gene-environment interactions might produce a meaningful improvement in quantification of the genetic determinants of CAD. Testing for gene-gene and gene-environment interactions is thus a new frontier for large-scale GWASs of CAD. There are several anecdotal examples of monogenic susceptibility to CAD in which the phenotype was worsened by an adverse environment. In addition, small-scale candidate gene association studies with functional hypotheses have identified gene-environment interactions. For future evaluation of gene-gene and gene-environment interactions to achieve the same success as the single gene associations reported in recent GWASs, it will be important to pre-specify agreed standards of study design and statistical power, environmental exposure measurement, phenomic characterization and analytical strategies. Here we discuss these issues, particularly in relation to the investigation and potential clinical utility of gene-gene and gene-environment interactions in CAD.
\end{abstract}

\section{Introduction}

Genetic investigations of coronary artery disease (CAD) aim to identify functional variants to assist with its diagnosis, prognosis or treatment. The full spectrum of DNA variant sizes and frequencies, ranging from single nucleotide changes to large copy number variations and from rare mutations to common polymorphisms, are components of a comprehensive approach to identify genetic determinants of CAD. However, $\mathrm{CAD}$ is the terminal manifestation of multiple intermediate disease processes, which individually have genetic and environmental determinants (Figure 1). For genetic research into $\mathrm{CAD}$ to be truly comprehensive, experimental methods must identify environmental and genetic factors and their interactions $[1,2]$.
It seems reasonable that the effect of a CAD susceptibility allele could differ depending on the context of other genetic or environmental factors. For instance, is it effective to search for a gene underlying type 2 diabetes mellitus (T2DM) in high performance athletes? Although such athletes may be genetically predisposed to T2DM, their activity levels would probably protect them from expressing the phenotype. However, although gene-gene or gene-environment interactions seem to be an obvious topic for consideration, the analysis of such interactions is not yet routine in genetic studies of CAD. Here, we will focus on interaction types, strategies to detect interactions, potential biases and the statistical issues involved in studying gene-gene and geneenvironment interactions in CAD. 


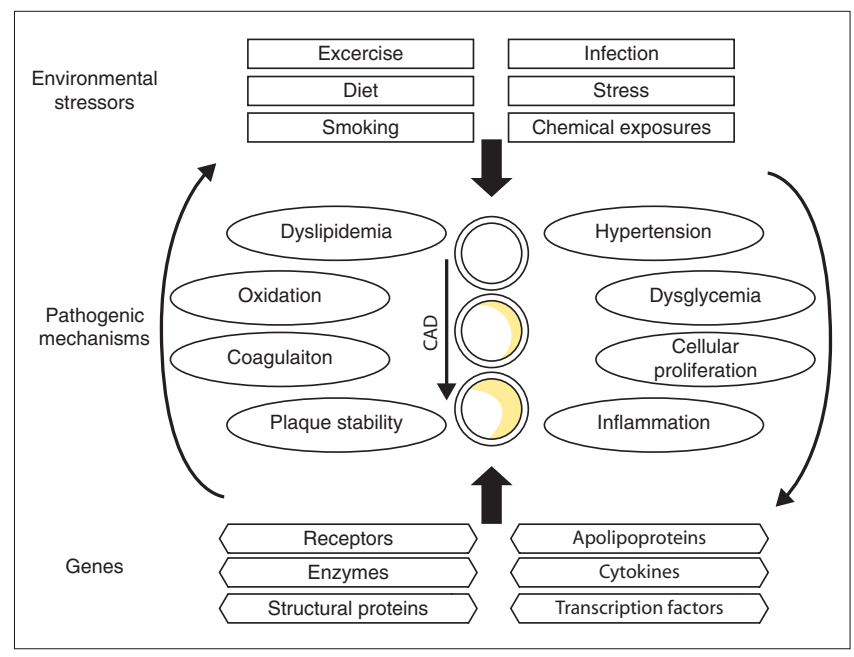

Figure I

The pathophysiology of coronary artery disease (CAD) is affected by environmental and genetic factors and their interactions. Pathogenic mechanisms contributing to plaque development and subsequent $C A D$ can be affected both negatively and positively by environmental exposures and genes. Environmental exposures can be either discrete (presence or absence) or continuous. Typically, CAD associated mutations and polymorphisms are found in genes encoding proteins that have key roles in intermediate pathways. Neither the environmental nor genetic lists shown here are comprehensive.

\section{Types of interactions}

Broadly defined, interactions are differences in the strength of association between a gene and phenotype on the basis of the presence of, absence of or quantitative differences in an additional factor, which could be another genetic variant or an environmental exposure. There are several putative models for gene-environment interactions, including synergy, modification of effects and redundancy (Figure 2). For a genegene interaction, the additional factor might be dichotomous, such as carrier versus non-carrier status, or additive, such as zero, one or two copies of the minor allele. For a gene-environment interaction, the additional factor can similarly be dichotomous, such as presence or absence of smoking history, or it can be a continuous variable, such as number of pack-years smoked.

\section{Role of interactions in genetic association studies}

Recent advances in cost-effective, array-based, highthroughput genotyping platforms have led to a flood of investigations of common single nucleotide polymorphisms (SNPs) in various diseases. Genome-wide association studies (GWASs) have successfully identified genetic determinants of CAD and its component risk factors [3-16]. For instance, several investigations found a region of chromosome 9p21 that was associated with CAD independently of traditional risk factors [3-6]. Furthermore, multiple genetic associations for T2DM $[7,17]$ and body mass index (BMI)

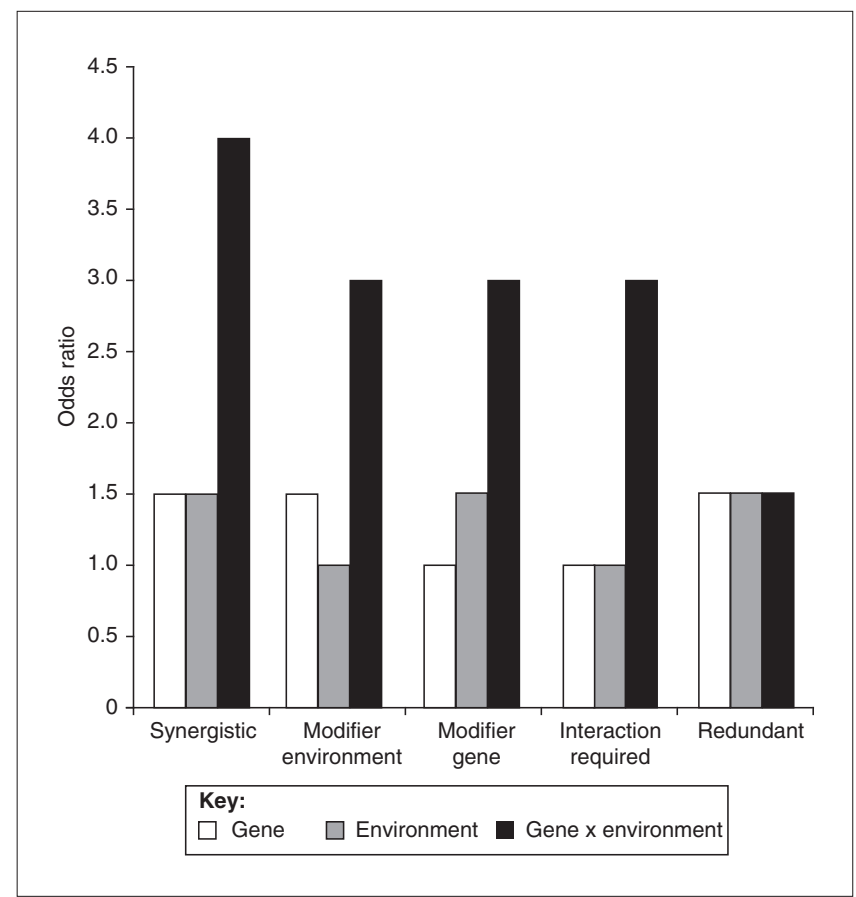

Figure 2

Putative gene-environment interactions. For even the simplest case, a dichotomous genetic risk factor (for example, carriers versus noncarriers) and a dichotomous environmental risk factor (for example, present versus absent), several types of interactions are possible. If both the gene and environment have main effects (odds ratios $>I$ ), and thus could be identified independently, a synergistic interaction would result in an effect size larger than a simple additive effect. A second possibility is that an environmental factor could have no main effect but could modify the effect of a genetic factor that does have a main effect, creating a larger than expected combined effect. The inverse is also possible, in which a modifier gene with no main effect of its own increases the effect size of an environmental risk factor. A fourth possibility is that neither the gene nor the environment has a detectable main effect, and interaction is required to produce a measurable effect. A fifth possibility is for a gene and an environmental factor to have redundant effects, in which case the combination of factors produces no increase in risk. These types of interactions can be extended to include different effect sizes or gene-gene interactions.

[18] have been discovered. However, most associated loci from GWASs have been reported for lipoprotein traits, including over 30 loci associated with plasma concentrations of low-density lipoprotein (LDL) cholesterol, high-density lipoprotein (HDL) cholesterol and triglyceride [7-16]. The success in finding genetic associations with lipoprotein phenotypes was due to methodological standardization (accuracy and precision) in trait measurement and to evaluation of large sample sizes, allowing detection of relatively subtle effects. Metaanalyses and collaborative consortia with large sample sizes have allowed GWASs to detect risk variants with low minor allele frequencies $(<5 \%)$ and small effect sizes (odds ratio of about 1.1 to 1.7) (Box 1); SNP association studies may have already reached their limit to detect clinically or 
biologically relevant loci with such effect sizes $[8,11,13,17,18]$.

Despite recent success in identifying CAD-associated SNPs, much of the genetic component of $\mathrm{CAD}$ and its risk factors remains unattributed. Forcing additional genetic markers with small effect sizes into predictive models only marginally improves prediction over traditional risk factors [19]. However, accounting for gene-gene and gene-environment interactions might produce a meaningful increase in the combined effect of the genetic determinants $[1,2]$. To ensure a valid assessment of gene-gene and gene-environment interactions, standards are required for sample sizes, accuracy and precision for continuous data, specificity and sensitivity for discrete data and appropriate statistical methods. Phenomics, defined as the comprehensive characterization of phenotype and environmental exposure [20], is also of key importance.

\section{Identification of small effect genetic and environmental factors}

So far, most genetic association studies have evaluated effects on intermediate phenotypes or pathogenic mechanisms, which can themselves be considered disease processes. For CAD, these intermediate phenotypes include blood coagulability, hypertension, altered lipid metabolism, cell proliferation and inflammation. When a new gene or locus is discovered, such as the chromosome 9p21 region associated with early CAD [3-6], and its association is subsequently replicated in multiple study samples [21-24], the basis of the association with CAD is assumed to be mediated through a pathogenic pathway [22]. This assumption will guide the design of subsequent functional experiments. Similarly, newly identified environmental determinants might exert their influence through one or even several pathogenic mechanisms and might even help identify previously unappreciated pathways.

Although the effect sizes of SNP associations identified in GWASs of CAD are modest, they are still important because: (i) individual associations can be combined to obtain larger cumulative effects; (ii) genes with small effects in GWASs can point to targets for drug-based or other interventions; (iii) genes with small effects in GWASs might contain rare, large-effect mutations in more severely affected patients; (iv) some GWAS loci with no previous CAD association might unveil new pathways; and (v) the effects of a GWAS locus could be amplified by gene-gene or gene-environment interactions.

These principles can be extended to the study of geneenvironment interactions. For instance: (i) individual environmental interactions could be combined to obtain a cumulatively larger effect; (ii) rare extreme environmental exposures may display larger effects on the CAD phenotype than more common or typical environmental variation; (iii) identification of gene-environment interactions might suggest new hypotheses to evaluate disease-causing mechanisms. These principles could direct the design of future studies of gene-environment interactions in CAD.

\section{Minor versus major alleles as a risk factor for CAD}

How do alleles affecting CAD susceptibility arise? DNA mutagenesis could provide a basis for understanding the generation of risk alleles. Several mutagenic mechanisms have been identified [25]. If a DNA error escapes repair and becomes embedded in the genome, it could, by affecting the expression or function of a protein, modify CAD risk either positively or negatively. If the recently mutated allele increases CAD risk, it is possible that genetic drift, inbreeding, pleiotropy, heterozygote advantage or small effects on reproductive fitness could be responsible for the allele reaching appreciable frequencies in the population [26]. For CAD, mortality typically occurs after the reproductive years, thus reducing selection pressure against deleterious alleles. Another possibility is that an environmental change might cause an allele that once had a neutral or beneficial effect to become deleterious.

Alternatively, if the mutated allele is beneficial, reducing CAD risk, one would expect the allele to increase in frequency to become the major allele. If the mutation occurred relatively recently, it is possible the minor allele is gradually becoming more prevalent. Such 'protective' minor alleles, or conversely major alleles that increase CAD risk, are possibly important from a public health perspective, since defining a gene-environment interaction might suggest an environmental intervention with a potentially large impact, due to the high population prevalence of the risk allele.

\section{Analytical detection strategies}

Gene-gene and gene-environment investigations have included family-based and population-based samples in retrospective and prospective designs. Statistical methods have included methods modifying regression and chisquared analyses, as well as statistical classification techniques, such as neural networks, support vector machines or Bayesian networks (Table 1). Although the statistical methods used in GWASs are fairly consistent and include regression and chi-squared analysis [3-8,10-18,27-30], the statistical approaches to detect gene-gene and gene-environment interactions are somewhat less standardized at present.

Investigators have tested for association between the cumulative number of risk alleles at multiple independent loci and disease [11,27,28]. Absolute allele counts [28] and relative weighting of alleles on the basis of their effect size $[11,27]$ have both been reported. Although this showed that the alleles were independent and their effects could be 
Table I

Summary of strategies to detect gene-gene and gene-environment interactions

\begin{tabular}{|c|c|c|c|}
\hline Analytical strategy & Advantages & Disadvantages & References \\
\hline $\begin{array}{l}\text { Examine the effect of the cumulative number of } \\
\text { risk alleles at multiple loci }\end{array}$ & Simple; shows independence of loci & No interaction measured & {$[11,27,28]$} \\
\hline $\begin{array}{l}\text { Compare effect of risk allele in sample subgrouped } \\
\text { by environmental exposure or additional genotype }\end{array}$ & Simple & $\begin{array}{l}\text { Substantial loss of power in } \\
\text { subgroups }\end{array}$ & {$[13,31,32]$} \\
\hline $\begin{array}{l}\text { Identify risk allele whose association with } \\
\text { phenotype is modulated by inclusion of } \\
\text { environmental or genetic covariate }\end{array}$ & Easy to implement & Multiple comparisons & {$[11,33,34]$} \\
\hline Inclusion of interaction term in regression model & $\begin{array}{l}\text { Direct modeling of gene-gene or } \\
\text { gene-environment interaction }\end{array}$ & $\begin{array}{l}\text { Need to define multiple } \\
\text { terms in model; possibility of } \\
\text { over-fitting; multiple comparisons }\end{array}$ & {$[13,33,34,55,56]$} \\
\hline $\begin{array}{l}\text { Non-linear statistical classification techniques, } \\
\text { including Bayesian networks, neural networks } \\
\text { and support vector machines }\end{array}$ & $\begin{array}{l}\text { Large volumes of data in } \\
\text { model-free manner }\end{array}$ & $\begin{array}{l}\text { Difficult to interpret; require } \\
\text { validation datasets }\end{array}$ & {$[29,30,34,35,57,58]$} \\
\hline
\end{tabular}

added, no interaction between the alleles was measured. Subgroup analyses, in which the strength or effect size of the association is compared between sample subgroups, have substantially less power to detect an association than the original intact sample, increasing the risk of false negative results. For example, assuming $80 \%$ power to detect a difference in allele frequencies between cases and controls within one subgroup, the second equally sized subgroup will yield disparate results about $30 \%$ of the time just by chance. The clinical trial literature contains many examples of inappropriate subgroup analyses [31], and one excellent review examines the lack of consistency of sex-specific subgroup genetic associations [32].

Regression techniques can be modified to test for gene-gene or gene-environment interactions, either by including additional interaction terms in the model or testing association with or without an additional covariate. Careful reviews of regression approaches to study interactions show the multitude and complexity of these techniques [33,34]. Finally, sophisticated statistical classification techniques, including but not limited to neural networks [29], support vector machines [35] and Bayesian networks [30], are being updated to accommodate analysis of interactions.

\section{Multiple comparisons}

If $\mathrm{N}$ genetic variants are entered into an analysis, $\mathrm{N}^{*}(\mathrm{~N}-1) / 2$ potentially interacting pairs can be constructed. Selecting $a$ priori known functional SNPs, or SNPs with coinciding spatial or temporal expression patterns, is one approach to reduce the number of tests. An alternative approach is first to test for marginal main effects in a primary hypothesisgenerating analysis and then to test for interactions between those significant effects in a second analysis in which the nominal level of significance has not been substantially adjusted [33]. In GWASs, permutation testing, control of false discovery rates and Bonferroni correction have been used to determine appropriate significance thresholds. Whatever approach is used, care will be required for selecting the nominal level of significance in gene-gene and gene-environment investigations.

\section{Potential biases in gene-gene and gene-environment investigations of CAD}

Many types of biases can affect gene-gene and gene-environment interactions (Table 2). The accuracy and precision of genotyping technologies render genetic investigations relatively resistant to measurement bias, compared to other sources of potential bias. Unequivocal disease phenotypes, such as myocardial infarction or coronary bypass surgery, are least susceptible to measurement bias. New imaging techniques, such as ultrasound-based intima-media thickness or magnetic resonance imaging (MRI)-based plaque volume calculations, are more susceptible to systematic errors of measurement. Self-reported measures of environmental exposure, such as caloric intake, energy expenditure or alcohol use, are most vulnerable to biases. Strategies to maximize the sensitivity and specificity of environmental factor measurement will improve the likelihood of detecting a significant association signal for interactions with genetic determinants [36].

Study design can affect bias, because prospective cohort studies are generally more resistant to bias than retrospective case-control designs [1]. Survivorship bias and population stratification are less common in prospective studies, assuming a truly representative cross-sectional cohort. Survivorship bias is a potential liability of retrospective studies of CAD, because patients with a fatal first myocardial infarction (up to $30 \%$ of cases) cannot be included in future studies. Recall bias, in which the study participant is more likely to remember an environmental exposure if it is 
Table 2

Potential biases in gene-gene and gene-environment investigations of coronary artery disease (CAD)

\begin{tabular}{|c|c|c|}
\hline Bias & General description & Application to CAD \\
\hline Selection bias & Skew in the selection of study participants & $\begin{array}{l}\text { Patients with strong family history may self-select for study participation; } \\
\text { patients with strong family history may be more likely to be referred to } \\
\text { tertiary care and research centers }\end{array}$ \\
\hline $\begin{array}{l}\text { Survivor bias } \\
\text { (prevalence-incidence } \\
\text { bias) }\end{array}$ & $\begin{array}{l}\text { Selection of study participants may miss } \\
\text { mild disease or severe fatal cases }\end{array}$ & $\begin{array}{l}\text { Patients whose first myocardial infarction is fatal are less likely to be } \\
\text { studied }\end{array}$ \\
\hline Recall bias & $\begin{array}{l}\text { Patients are more likely to recall an } \\
\text { environmental exposure if it was linked to a } \\
\text { negative outcome }\end{array}$ & $\begin{array}{l}\text { Patients with CAD may be more likely to remember an environmental } \\
\text { exposure because of its negative consequences }\end{array}$ \\
\hline Respondent bias & $\begin{array}{l}\text { Patients answer in the way they believe they } \\
\text { should answer, not the true answer }\end{array}$ & $\begin{array}{l}\text { Patients with CAD and knowledge of potential CAD risk factors will be } \\
\text { more motivated to report those exposures }\end{array}$ \\
\hline $\begin{array}{l}\text { Family information } \\
\text { bias }\end{array}$ & $\begin{array}{l}\text { Individuals become more aware of exposure if } \\
\text { it is prevalent in their family }\end{array}$ & Many CAD risk factors and environmental exposures cluster in families \\
\hline $\begin{array}{l}\text { Exposure suspicion } \\
\text { bias }\end{array}$ & $\begin{array}{l}\text { Disease status can affect the amount of } \\
\text { environmental exposure history collected }\end{array}$ & $\begin{array}{l}\text { If data collection is not standardized, investigators may more thoroughly } \\
\text { query patients with CAD }\end{array}$ \\
\hline Publication bias & $\begin{array}{l}\text { Statistically significant findings are more likely } \\
\text { to be published }\end{array}$ & $\begin{array}{l}\text { Gene-gene and gene-environment interaction findings in CAD are more } \\
\text { likely to be published if significant }\end{array}$ \\
\hline Measurement bias & Systematic errors of measurement & $\begin{array}{l}\text { Platform- or laboratory-dependent genotyping errors; errors of laboratory } \\
\text { values; errors of environmental exposure measurement }\end{array}$ \\
\hline $\begin{array}{l}\text { Population } \\
\text { stratification }\end{array}$ & $\begin{array}{l}\text { Differences in allele frequencies between groups } \\
\text { resulting from ancestry not outcome status }\end{array}$ & $\begin{array}{l}\text { CAD prevalence varies between ethnicities; but this can be tested and } \\
\text { corrected for using methodological and statistical techniques }\end{array}$ \\
\hline
\end{tabular}

associated with a negative outcome, respondent bias, in which patients alter their answers to exposure questions following a negative outcome, and exposure suspicion biases, in which investigators query individuals who have a negative outcome more thoroughly, are all reduced in prospective designs, as long as environmental exposure information is collected from all study participants irrespective of $\mathrm{CAD}$ outcomes.

\section{Statistical power}

Statistical power is directly proportional to the number of study participants and to the size of the effect under study. Factors to be included in power calculations of all genetic investigations include the minor allele frequency, the degree of linkage disequilibrium between the queried marker and the hypothetical disease locus, the genotype error rate and the genetic or phenotypic heterogeneity (Box 2). Fortunately, high-throughput genotyping platforms have a negligible genotype error rate [37]. Correction for multiple comparisons and the measurement error of environmental exposures also influence study power $[1,2]$. As a result of the greater accuracy of genotyping compared with the measurement or report of environmental exposures, there is theoretically more power to detect a gene-gene interaction than a geneenvironment interaction for the same sized sample. Studies with inaccurate or imprecise measurement of phenotype or environmental exposure may require up to 20 times larger samples to detect an association signal above background noise [36]. However, the power advantage of gene-gene investigations resulting from their higher measurement accuracy is diminished by the need to correct for multiple comparisons and by the potentially increased complexity of interactions compared with gene-environment investigations.

How large a sample is required for adequate power to find gene-gene and gene-environment interactions? A rule of thumb is that a four-fold increment in sample size is required to test for a multiplicative interaction of two main effects [2,38]. This may overestimate the sample size requirement, especially if the effect of the interaction is larger than the main effects, but it illustrates the general requirement for a larger sample size when interactions are introduced into hypothesis testing. Given that many previous candidate gene studies, and even many GWASs, were powered to detect only main effects, testing these samples for gene-gene and gene-environment interactions has the potential for false positive and false negative results $[2,3]$. Higher-order interactions will require even larger samples to attain suitable power and may not be possible even among the largest current association studies [1].

\section{Examples of interactions in monogenic CAD}

Studies of monogenic susceptibility to CAD have revealed several gene-gene and gene-environment interactions. For 


\section{Box 1. Glossary of statistical terms}

Bias: a tendency leading to conclusions that systematically differ from the truth, typically resulting from inadequate study design or poor methodology.

Bonferroni correction: in multiple hypothesis testing, a conservative adjustment of the significance threshold achieved by dividing the nominal significance threshold by the number of tests performed in order to control the number of false positive (type 1) errors.

Effect size: the change in the dependent variable - typically the trait value or likelihood of disease phenotype - that is associated with a given change of the independent variable - typically the number of minor alleles or risk allele carrier status of an individual.

False discovery rate: in multiple hypothesis testing, a group of methods in which the primary goal is to control the number of false negatives (type 2 error rate), as opposed to false positives (type 1 error rate).

Interaction effect: the effect size of the combination of two or more independent variables, when the main effect of the variables individually is excluded.

Main effect: used in multivariate study designs, the effect size of the independent variable on the dependent variable, excluding other possible independent variables.

Permutation testing: a computational technique to estimate statistical significance by comparing the actual observed test result with the distribution of all possible test results that can be generated by swapping trait values or disease status between study participants.

Population stratification: allele frequency differences that occur between sample subgroups because of differences in genetic ancestry rather than a direct role of the alleles in disease susceptibility.

Regression: an encompassing term to denote a group of statistical methods that attempt to model the relationship between a dependent variable using one or more independent variables. The model typically contains multiple terms, with each term usually comprising a dependent variable or combination of dependent variables with weighting factors.

Significance threshold: the statistical significance, or the probability that the observation has occurred by chance, that needs to be overcome before declaring an association as true.

Statistical classification: a group of non-linear statistical techniques that attempt to group or classify an individual on the basis of patterns of descriptive variables derived from a previously examined pool of data.

Statistical power: the probability that a statistical test will correctly reject the null hypothesis.

instance, age at death from $\mathrm{CAD}$ was studied in large Mormon families with familial hypercholesterolemia (FH) attributable to rare heterozygous mutations in the $L D L R$ gene [39,40]. Carriers of $L D L R$ mutations who lived in the 19th century had survived to the eighth and ninth decades of life, whereas carriers of $L D L R$ mutations who lived in the 2oth century died early with CAD, often in the third and fourth decades of life [39,40]. The most likely explanation for this observation was a healthier environment in past times, including higher physical activity and lower saturated fat consumption compared with the contemporary environment $[39,40]$. Similar conclusions were reached with multigenerational studies of FH patients in the Netherlands [41]. Other investigators found that Chinese FH heterozygotes who had immigrated to North America had worsened biochemical and clinical phenotypes than carriers of the same LDLR mutations living in China [42]. The difference in disease severity was ascribed to differences in dietary fat consumption; these circumstantial observations strongly suggested that environmental factors, such as diet and activity level, modulated the phenotype of heterozygous FH.

From our personal experience, there are other examples of monogenic illnesses whose severity can be significantly modulated by the environment - mainly diet and activity. For instance, we have seen the severity of expression of the disease phenotype made worse by an adverse environment in patients with hypertriglyceridemia due to apo CII-T [43], with analphalipoproteinemia due to $A P O A 1 \mathrm{Q}[-2] \mathrm{X}$ [44], with T2DM due to $H_{N F} A$ G319S [45] and with metabolic complications and CAD in familial partial lipodystrophy due to LMNA R482Q [46].

\section{Examples of interactions with common SNPs}

Although interactions between environment and disease penetrance in rare monogenic disorders are instructive, a much larger potential impact could be seen in common 
Table 3

Examples of replicated gene-gene and gene-environment interactions in CAD

\begin{tabular}{|c|c|c|c|c|}
\hline Gene & Environment & Interaction & $\begin{array}{l}\text { Independently associated } \\
\text { with CAD? }\end{array}$ & References \\
\hline$L D L R$ & Lifestyle & $\begin{array}{l}\text { Rare mutations have larger effect in less active people } \\
\text { with high-fat diet }\end{array}$ & LDLR: yes; lifestyle: yes & {$[40,42]$} \\
\hline GSTMI, GSTTI & Smoking & Elevated CAD risk in smokers with null mutations & $\begin{array}{l}\text { GSTMI, GSTTI: weak; } \\
\text { smoking: yes }\end{array}$ & {$[47,48]$} \\
\hline$A P O E$ & Smoking & $\begin{array}{l}\text { Exaggerated smoking-associated CAD risk in carriers } \\
\text { of APOE } \varepsilon 4\end{array}$ & APOE: yes; smoking: yes & {$[49,50]$} \\
\hline$A D H I C$ & Alcohol consumption & $\begin{array}{l}\text { Slow-metabolizing } \gamma 2 \text { allele homozygotes have the } \\
\text { greatest CAD protection }\end{array}$ & ADHIC: weak; alcohol: yes & {$[57,58]$} \\
\hline$F G B$ & Strenuous exercise & $\begin{array}{l}\text { Carriers of } 455 \mathrm{~A} \text { allele have exaggerated increase in } \\
\text { fibrinogen after exercise }\end{array}$ & FGB: no; exercise: yes & {$[51,52]$} \\
\hline$F / 3 A I$ & Plasma fibrinogen & $\begin{array}{l}\text { Leu34 is protective for CAD in people with high } \\
\text { fibrinogen levels }\end{array}$ & FI3AI: no; fibrinogen: yes & {$[53,54]$} \\
\hline$A C E, A G T$ & & Unclear multi-locus epistatic interactions & ACE: no; AGT: no & {$[59,60]$} \\
\hline$L P L, A P O E$ & & $\begin{array}{l}\text { Greater negative effect of rare LPL alleles in } \\
\text { APOE } \varepsilon 4 \text { carriers }\end{array}$ & LPL: yes; APOE: yes & {$[55,56]$} \\
\hline
\end{tabular}

Abbreviations: $A C E$, acetylcholine esterase; $A D H I C$, alcohol dehydrogenase IC; $A G T$, angiotensinogen; $A P O E$, apolipoprotein $\mathrm{E}$; $F G B$, fibrinogen beta chain; FI3AI, coagulation factor XIII, subunit AI; GSTMI, glutathione S-transferase mu I; GSTTI, glutathione S-transferase theta I; LDLR, low-density lipoprotein receptor; $L P L$, lipoprotein lipase.

complex CAD susceptibility because of small-effect common SNPs. The effect of the environment might be even more pronounced in patients whose phenotypes are caused by the aggregation of small contributions from many genetic and non-genetic factors. Examples of replicated gene-gene and gene-environment interactions identified in investigations of common SNPs in candidate genes are shown in Table 3. For instance, increased CAD risk has been observed in smokers with null genotypes for glutathione $S$-transferases, which are involved in the detoxification of carcinogens and products of oxidative stress $[47,48]$. Furthermore, smokers who are carriers of at least one $A P O E$ E4 allele seem to have significantly higher concentrations of oxidized LDL cholesterol compared with non-carriers, potentially further increasing CAD risk [49,50]. Humphries and colleagues report a robust association between the $-455 \mathrm{G}>\mathrm{A}$ SNP of the fibrinogen beta chain $(F G B)$ gene and elevated post-exercise fibrinogen levels $[51,52]$. Elevated fibrinogen levels may modulate the myocardial infarction risk associated with the Leu34 allele of blood coagulation factor XIII ( $F 13 A 1)$, a tetrameric zymogen that protects the fibrin clot from proteolytic degradation [53,54]. These candidate gene-environment interactions were examined because of plausible biological relationships, but large-scale replications are still required, with careful attention to the issues raised in this article.

\section{Examples from GWASs}

Gene-gene or gene-environment interactions are not yet routinely evaluated in GWASs, but two recent reports include exploratory examinations. Kathiresan and colleagues performed a two-stage GWAS of plasma lipoproteins [11]. The first stage identified over 1,00o associated SNPs in 25 loci $\left(p<5 \times 10^{-8}\right)[11]$. The second stage analysis re-tested all SNPs using 36 of the significantly associated SNPs from the first stage as covariates in the regression. The number of associated SNPs was reduced to 105 in 7 loci $\left(p<5 \times 10^{-8}\right)$ [11]. All loci identified in the second stage had been identified in the first stage of analysis, suggesting that additional SNPs in known loci - that are not in linkage disequilibrium with the SNPs used as covariates - are associated with lipoprotein traits.

Sabatti and colleagues examined genome-wide gene-environment interactions, with the caveat that the work was underpowered to confidently identify interactions [13]. They examined four dichotomized environmental variables (sex, use of oral contraceptives, BMI over $25 \mathrm{~kg} / \mathrm{m}^{2}$ and gestational age), comparing differences in effect size between the two subgroups and two variables separated into quintiles (birth BMI and early growth), which were tested by regression using an interaction term [13]. At least one interaction SNP was identified $\left(p<5 \times 10^{-7}\right)$ for five out of six environment variables, although none of the SNPs were in genes with a main effect or with known biological relevance [13].

These findings represent possible novel associations with metabolic CAD risk factors, but replication in larger samples is required. The issues discussed above in relation to study design, power and analytic strategies to detect gene-gene 


\section{Box 2. Factors affecting the statistical power of a study of gene-gene or gene-environment interactions}

- Number of study participants

- ratio of cases to controls

- Effect size of risk factor

- proportional to standard deviation of trait

- Measurement error of disease trait or environmental exposure

- accuracy and precision of quantitative trait measurement

- $\quad$ sensitivity and specificity for dichotomous measurements

- Genotyping error rate

- especially pertinent when examining copy number variation

- Minor allele frequency of genetic variant

- affected by disease model if grouped into carrier versus non-carrier

- Linkage disequilibrium between queried variant and 'true' functional variant

- Significance threshold

- needed to correct for multiple tests, to an even greater degree in multi-way tests for gene-gene or gene-environment interactions

- Genetic heterogeneity

- different variants in the same locus, or in multiple loci, lead to the same phenotype

- Phenotypic heterogeneity

- different phenotypes are produced as a result of the same genetic variation

- Type of interaction and size of interaction effect

and gene-environment interactions are relevant to these large multi-center population studies, as these studies will form the precedent for future investigations.

\section{Clinical implications}

Accounting for gene-gene and gene-environment interactions will probably be important for future strategies of diagnosis, prognosis and management of CAD. For instance, current treatment guidelines for $\mathrm{CAD}$ prevention require risk stratification of the patient. CAD risk strata in a currently disease-free patient are calculated using traditional epidemiological risk factors, such as older age, male sex, the presence of cigarette smoking, diabetes, hypertension, dyslipidemia and, in some models, a family history of early CAD. Quantification of the patient's CAD risk using these variables guides the intensity of evidence-based drug treatment of modifiable risk factors, such as hypertension and dyslipidemia. It certainly seems feasible that reliable molecular genetic information can be included in future risk stratification models, improving precision over simply docu- menting a family history of CAD. Furthermore, combinations of specific genetic variables in the context of specific environmental variables - reflecting both gene-gene and gene-environment interactions - could help to re-stratify an individual between risk strata derived using non-molecular data. Also, given that such environmental factors as diet, activity level, stress, smoking and air quality are known to be important determinants of CAD risk, the first line of costeffective and safe intervention for an individual with a high genetic risk burden would include modulation of such environmental factors instead of more costly, high-tech approaches, such as gene-based biological therapies.

\section{Conclusions}

In the context of GWAS datasets, gene-gene and geneenvironment interactions are a new frontier for CAD association studies. GWASs have been extremely successful in identifying individual loci for CAD susceptibility, but the practical limits of sample size and array resolution for the identification of biologically valid loci will soon be reached. 
As a result of the high prevalence of CAD and the presence of large, multi-center prospective cohort initiatives with genotyping on high-density DNA genotyping arrays, gene-gene and gene-environment interaction studies of $\mathrm{CAD}$ will be possible in the future. Rigorous testing for gene-gene and gene-environment interactions should be built into the experimental study design. To ensure that testing for interactions enjoys the same success as GWASs of CAD, precise standards, including suitable sample sizes, reliable methods for measurement of environmental exposures, phenomic characterization and statistical analyses, will be required to minimize both false negative and false positive findings and to allow findings to be compared across samples and reports. The increment in the understanding of CAD susceptibility provided through systematic study and replication of gene-gene and gene-environment interactions will permit a more complete set of tools for diagnosis, disease prediction and prognosis and tailored therapy, perhaps using appropriate environment-based interventions.

\section{Abbreviations}

$\mathrm{BMI}$, body mass index; CAD, coronary artery disease; $F G B$, fibrinogen beta chain; $\mathrm{FH}$, familial hypercholesterolemia; $F 13 A 1$, blood coagulation factor XIII subunit A1; GWAS, genome-wide association study; HMGCR, 3-hydroxyl-3-methylglutaryl-CoA reductase; LDL, low-density lipoprotein; LDLR, low-density lipoprotein receptor; SNP, single nucleotide polymorphism; T2DM, type 2 diabetes.

\section{Competing interests}

The authors report no competing interests.

\section{Author contributions}

Both authors contributed to the conception and production of the manuscript and approved the final version.

\section{Acknowledgements}

MBL is supported by the Canadian Institute of Health Research MD/PhD Studentship Award and the University of Western Ontario MD/PhD Program. RAH holds the Edith Schulich Vinet Canada Research Chair (Tier I) in Human Genetics and the Jacob I Wolfe Distinguished Medical Research Chair at the University of Western Ontario. This work was supported by operating grants from the Heart and Stroke Foundation of Ontario (NA 6018), the Canadian Institutes for Health Research (MOP 13430 and 79533), the Jean Davignon Distinguished CardiovascularMetabolic Research Award (Pfizer, Canada), and Genome Canada through the Ontario Genomics Institute.

\section{References}

I. Manolio TA, Bailey-Wilson JE, Collins FS: Genes, environment and the value of prospective cohort studies. Nat Rev Genet 2006, 7:812-820.

2. Hunter DJ: Gene-environment interactions in human diseases. Nat Rev Genet 2005, 6:287-298.
3. Welcome Trust Case Control Consortium: Genome-wide association study of 14,000 cases of seven common diseases and 3,000 shared controls. Nature 2007, 447:66 I-678.

4. Helgadottir A, Thorleifsson G, Manolescu A, Gretarsdottir S, Blondal T, Jonasdottir A, Jonasdottir A, Sigurdsson A, Baker A, Palsson A, Masson G, Gudbjartsson DF, Magnusson KP, Andersen K, Levey AI, Backman VM, Matthiasdottir S, Jonsdottir T, Palsson S, Einarsdottir H, Gunnarsdottir S, Gylfason A, Vaccarino V, Hooper WC, Reilly MP, Granger CB, Austin H, Rader DJ, Shah SH, Quyyumi AA, et al.: A common variant on chromosome $9 \mathrm{p} 21$ affects the risk of myocardial infarction. Science 2007, 316:149|-1493.

5. McPherson R, Pertsemlidis A, Kavaslar N, Stewart A, Roberts R, Cox DR, Hinds DA, Pennacchio LA, Tybjaerg-Hansen A, Folsom AR, Boerwinkle $\mathrm{E}$, Hobbs $\mathrm{HH}$, Cohen JC: A common allele on chromosome 9 associated with coronary heart disease. Science 2007, 316:1488-|49|.

6. Samani NJ, Erdmann J, Hall AS, Hengstenberg C, Mangino M, Mayer B, Dixon RJ, Meitinger T, Braund P, Wichmann HE, Barrett JH, Konig IR, Stevens SE, Szymczak S, Tregouet DA, lles MM, Pahlke F, Pollard $\mathrm{H}$, Lieb W, Cambien F, Fischer M, Ouwehand W, Blankenberg S, Balmforth AJ, Baessler A, Ball SG, Strom TM, Braenne I, Gieger C, Deloukas $\mathrm{P}$, et al:: Genomewide association analysis of coronary artery disease. N Engl J Med 2007, 357:443-453.

7. Saxena R, Voight BF, Lyssenko V, Burtt NP, de Bakker PI, Chen H, Roix JJ, Kathiresan S, Hirschhorn JN, Daly MJ, Hughes TE, Groop L, Altshuler D, Almgren P, Florez JC, Meyer J, Ardlie K, Bengtsson Bostrom K, Isomaa B, Lettre G, Lindblad U, Lyon HN, Melander O, Newton-Cheh C, Nilsson P, Orho-Melander M, Rastam L, Speliotes EK, Taskinen MR, Tuomi T, et al:: Genome-wide association analysis identifies loci for type 2 diabetes and triglyceride levels. Science 2007, 316:133|-|336.

8. Aulchenko YS, Ripatti S, Lindqvist I, Boomsma D, Heid IM, Pramstaller PP, Penninx BW, Janssens AC, Wilson JF, Spector T, Martin NG, Pedersen NL, Kyvik KO, Kaprio J, Hofman A, Freimer NB, Jarvelin MR, Gyllensten U, Campbell H, Rudan I, Johansson A Marroni F, Hayward C, Vitart V, Jonasson I, Pattaro C, Wright A, Hastie N, Pichler I, Hicks AA, et al:: Loci influencing lipid levels and coronary heart disease risk in 16 European population cohorts. Nat Genet 2009, 41:47-55.

9. Chasman DI, Pare G, Zee RYL, Parker AN, Cook NR, Buring JE, Kwiatkowski DJ, Rose LM, Smith JD, Williams PT, Rieder MJ, Rotter JI, Nickerson DA, Krauss RM, Miletich JP, Ridker PM: Genetic loci associated with plasma concentration of low-density lipoprotein cholesterol, high-density lipoprotein cholesterol, triglycerides, apolipoprotein $\mathrm{AI}$, and apolipoprotein B among 6382 white women in genome-wide analysis with replication. Circ Cardiovasc Genet 2008, I:21-31.

10. Kathiresan S, Melander O, Guiducci C, Surti A, Burtt NP, Rieder MI, Cooper GM, Roos C, Voight BF, Havulinna AS, Wahlstrand B, Hedner T, Corella D, Tai ES, Ordovas JM, Berglund G, Vartiainen E, Jousilahti P, Hedblad B, Taskinen MR, Newton-Cheh C, Salomaa V, Peltonen L, Groop L, Altshuler DM, Orho-Melander M: Six new loci associated with blood low-density lipoprotein cholesterol, highdensity lipoprotein cholesterol or triglycerides in humans. Nat Genet 2008, 40:189-197.

II. Kathiresan S, Willer CJ, Peloso GM, Demissie S, Musunuru K, Schadt EE, Kaplan L, Bennett D, Li Y, Tanaka T, Voight BF, Bonnycastle LL, Jackson AU, Crawford G, Surti A, Guiducci C, Burtt NP, Parish S, Clarke R, Zelenika D, Kubalanza KA, Morken MA, Scott LJ, Stringham HM, Galan P, Swift AJ, Kuusisto J, Bergman RN, Sundvall J, Laakso $M$, et al:: Common variants at $\mathbf{3 0}$ loci contribute to polygenic dyslipidemia. Nat Genet 2009, 4I:56-65.

12. Kooner JS, Chambers JC, Aguilar-Salinas CA, Hinds DA, Hyde CL, Warnes GR, Gomez Perez FJ, Frazer KA, Elliott P, Scott J, Milos PM, Cox DR, Thompson JF: Genome-wide scan identifies variation in MLXIPL associated with plasma triglycerides. Nat Genet 2008, 40:|49-|5|.

13. Sabatti C, Service SK, Hartikainen AL, Pouta A, Ripatti S, Brodsky J, Jones CG, Zaitlen NA, Varilo T, Kaakinen M, Sovio U, Ruokonen A, Laitinen J, Jakkula E, Coin L, Hoggart C, Collins A, Turunen H, Gabriel S, Elliot P, McCarthy MI, Daly MJ, Jarvelin MR, Freimer NB, Peltonen L: Genome-wide association analysis of metabolic traits in a birth cohort from a founder population. Nat Genet 2009, 4I:35-46.

14. Sandhu MS, Waterworth DM, Debenham SL, Wheeler E, Papadakis K, Zhao JH, Song K, Yuan X, Johnson T, Ashford S, Inouye M, Luben R, Sims M, Hadley D, McArdle W, Barter P, Kesaniemi YA, Mahley RW, McPherson R, Grundy SM, Bingham SA, Khaw KT, Loos RJ, 
Waeber G, Barroso I, Strachan DP, Deloukas P, Vollenweider P, Wareham NJ, Mooser V: LDL-cholesterol concentrations: a genomewide association study. Lancet 2008, 371:483-49I.

15. Wallace C, Newhouse SJ, Braund P, Zhang F, Tobin M, Falchi M, Ahmadi K, Dobson RJ, Marcano AC, Hajat C, Burton P, Deloukas P, Brown M, Connell JM, Dominiczak A, Lathrop GM, Webster J, Farrall M, Spector T, Samani NJ, Caulfield MJ, Munroe PB: Genomewide association study identifies genes for biomarkers of cardiovascular disease: serum urate and dyslipidemia. Am J Hum Genet 2008, 82:139-149.

16. Willer CJ, Sanna S, Jackson AU, Scuteri A, Bonnycastle LL, Clarke R, Heath SC, Timpson NJ, Najjar SS, Stringham HM, Strait J, Duren WL, Maschio A, Busonero F, Mulas A, Albai G, Swift AJ, Morken MA, Narisu N, Bennett D, Parish S, Shen H, Galan P, Meneton P, Hercberg S, Zelenika D, Chen WM, Li Y, Scott LJ, Scheet PA, et al:: Newly identified loci that influence lipid concentrations and risk of coronary artery disease. Nat Genet 2008, 40: I6I-169.

17. Prokopenko I, Langenberg C, Florez JC, Saxena R, Soranzo N, Thorleifsson G, Loos RJ, Manning AK, Jackson AU, Aulchenko Y, Potter SC, Erdos MR, Sanna S, Hottenga J], Wheeler E, Kaakinen M, Lyssenko V, Chen WM, Ahmadi K, Beckmann JS, Bergman RN, Bochud M, Bonnycastle LL, Buchanan TA, Cao A, Cervino A, Coin L, Collins FS, Crisponi L, de Geus EJ, et al:: Variants in MTNRIB influence fasting glucose levels. Nat Genet 2009, 41:77-8I

18. Loos RJ, Lindgren CM, Li S, Wheeler E, Zhao JH, Prokopenko I, Inouye M, Freathy RM, Attwood AP, Beckmann JS, Berndt SI, Jacobs KB, Chanock SJ, Hayes RB, Bergmann S, Bennett AJ, Bingham SA, Bochud M, Brown M, Cauchi S, Connell JM, Cooper C, Smith GD, Day I, Dina C, De S, Dermitzakis ET, Doney AS, Elliott KS, Elliott P, et al:: Common variants near MC4R are associated with fat mass, weight and risk of obesity. Nat Genet 2008, 40:768-775.

19. Lanktree M, Oh J, Hegele RA: Genetic testing for atherosclerosis risk: inevitability or pipe dream? Can J Cardiol 2008, 24:85I-854.

20. Joy T, Hegele RA: Genetics of metabolic syndrome: is there a role for phenomics? Curr Atheroscler Rep 2008, 10:201-208.

21. Anderson JL, Horne BD, Kolek MJ, Muhlestein JB, Mower CP, Park JJ, May HT, Camp NJ, Carlquist JF: Genetic variation at the 9p2I locus predicts angiographic coronary artery disease prevalence but not extent and has clinical utility. Am Heart J 2008, I 56: I I 55- I I 62.e2.

22. Broadbent HM, Peden JF, Lorkowski S, Goel A, Ongen H, Green F, Clarke R, Collins R, Franzosi MG, Tognoni G, Seedorf U, Rust S, Eriksson P, Hamsten A, Farrall M, Watkins H: Susceptibility to coronary artery disease and diabetes is encoded by distinct, tightly linked SNPs in the ANRIL locus on chromosome 9p. Hum Mol Genet 2008, 17:806-8|4.

23. Helgadottir A, Thorleifsson G, Magnusson KP, Gretarsdottir S, Steinthorsdottir V, Manolescu A, Jones GT, Rinkel GJ, Blankensteijn JD, Ronkainen A, Jaaskelainen JE, Kyo Y, Lenk GM, Sakalihasan N, Kostulas K, Gottsater A, Flex A, Stefansson H, Hansen T, Andersen G, Weinsheimer S, Borch-Johnsen K, Jorgensen T, Shah SH, Quyyumi AA, Granger CB, Reilly MP, Austin H, Levey AI, Vaccarino V, et al:: The same sequence variant on $9 p 21$ associates with myocardial infarction, abdominal aortic aneurysm and intracranial aneurysm. Nat Genet 2008, 40:217-224.

24. Schunkert $H$, Gotz A, Braund P, McGinnis R, Tregouet DA, Mangino $M$, Linsel-Nitschke P, Cambien F, Hengstenberg C, Stark K, Blankenberg S, Tiret L, Ducimetiere P, Keniry A, Ghori MJ, Schreiber S, El Mokhtari NE, Hall AS, Dixon RJ, Goodall AH, Liptau H, Pollard H, Schwarz DF, Hothorn LA, Wichmann HE, Konig IR, Fischer M, Meisinger C, Ouwehand W, Deloukas P, et al.: Repeated replication and a prospective meta-analysis of the association between chromosome 9p21.3 and coronary artery disease. Circulation 2008, I I7:1675-1684.

25. Fleck O, Nielsen O: DNA repair. J Cell Sci 2004, I I7:5 I 5-5I 7.

26. Crespi BJ: The evolution of maladaptation. Heredity 2000, 84:623629.

27. Scott LJ, Mohlke KL, Bonnycastle LL, Willer CJ, Li Y, Duren WL, Erdos MR, Stringham HM, Chines PS, Jackson AU, Prokunina-Olsson L, Ding CJ, Swift AJ, Narisu N, Hu T, Pruim R, Xiao R, Li XY, Conneely KN, Riebow NL, Sprau AG, Tong M, White PP, Hetrick KN, Barnhart MW, Bark CW, Goldstein JL, Watkins L, Xiang F, Saramies J, et al.: A genome-wide association study of type 2 diabetes in Finns detects multiple susceptibility variants. Science 2007, 3 | 6: I 34 | - I 345

28. Kathiresan S, Melander O, Anevski D, Guiducci C, Burtt NP, Roos C, Hirschhorn JN, Berglund G, Hedblad B, Groop L, Altshuler DM, Newton-Cheh C, Orho-Melander M: Polymorphisms associated with cholesterol and risk of cardiovascular events. N Engl J Med 2008, 358: I 240-1249.

29. Motsinger-Reif AA, Dudek SM, Hahn LW, Ritchie MD: Comparison of approaches for machine-learning optimization of neural networks for detecting gene-gene interactions in genetic epidemiology. Genet Epidemiol 2008, 32:325-340.

30. Mukherjee B, Ahn J, Gruber SB, Rennert G, Moreno V, Chatterjee $\mathrm{N}$ : Tests for gene-environment interaction from case-control data: a novel study of type I error, power and designs. Genet Epidemiol 2008, 32:615-626.

3I. Brookes ST, Whitely E, Egger M, Smith GD, Mulheran PA, Peters T]: Subgroup analyses in randomized trials: risks of subgroup-specific analyses; power and sample size for the interaction test. J Clin Epidemiol 2004, 57:229-236.

32. Patsopoulos NA, Tatsioni A, loannidis JP: Claims of sex differences: an empirical assessment in genetic associations. JAMA 2007, 298:880893.

33. Marchini J, Donnelly P, Cardon LR: Genome-wide strategies for detecting multiple loci that influence complex diseases. Nat Genet 2005, 37:4I3-4I7.

34. Musani SK, Shriner D, Liu N, Feng R, Coffey CS, Yi N, Tiwari HK Allison DB: Detection of gene $\mathbf{x}$ gene interactions in genome-wide association studies of human population data. Hum Hered 2007, 63:67-84.

35. Chen SH, Sun J, Dimitrov L, Turner AR, Adams TS, Meyers DA, Chang BL, Zheng SL, Gronberg H, Xu J, Hsu FC: A support vector machine approach for detecting gene-gene interaction. Genet Epidemiol 2008, 32:152-167.

36. Wong MY, Day NE, Luan JA, Chan KP, Wareham NJ: The detection of gene-environment interaction for continuous traits: should we deal with measurement error by bigger studies or better measurement? Int J Epidemiol 2003, 32:51-57.

37. Tung L, Gordon D, Finch SJ: The impact of genotype misclassification errors on the power to detect a gene-environment interaction using cox proportional hazards modeling. Hum Hered 2007, 63: I 0 I- I I 0.

38. Smith PG, Day NE: The design of case-control studies: the influence of confounding and interaction effects. Int J Epidemiol 1984, 13:356365 .

39. Williams RR, Hasstedt SJ, Wilson DE, Ash KO, Yanowitz FF, Reiber $\mathrm{GE}$, Kuida $\mathrm{H}$ : Evidence that men with familial hypercholesterolemia can avoid early coronary death. An analysis of 77 gene carriers in four Utah pedigrees. JAMA 1986, 255:219-224.

40. Hegele RA, Emi M, Wu LL, Hopkins PN, Williams RR, Lalouel JM: Clinical application of deoxyribonucleic acid markers in a Utah family with hypercholesterolemia. Am J Cardiol 1989, 63:109-I I 2.

4I. Sijbrands EJ, Westendorp RG, Defesche JC, de Meier PH, Smelt AH, Kastelein JJ: Mortality over two centuries in large pedigree with familial hypercholesterolaemia: family tree mortality study. BMJ 200I, 322:1019-1023.

42. Pimstone SN, Sun XM, du Souich C, Frohlich JJ, Hayden MR, Soutar AK: Phenotypic variation in heterozygous familial hypercholesterolemia: a comparison of Chinese patients with the same or similar mutations in the LDL receptor gene in China or Canada. Arterioscler Thromb Vasc Biol 1998, 18:309-315.

43. Hegele RA, Breckenridge WC, Cox DW, Maguire GF, Little JA, Connelly PW: Interaction between variant apolipoproteins C-II and E that affects plasma lipoprotein concentrations. Arterioscler Thromb I991, II:I303-1309.

44. Ng DS, Leiter LA, Vezina C, Connelly PW, Hegele RA: Apolipoprotein A-I Q[-2]X causing isolated apolipoprotein A-I deficiency in a family with analphalipoproteinemia. J Clin Invest 1994, 93:223-229.

45. Triggs-Raine BL, Kirkpatrick RD, Kelly SL, Norquay LD, Cattini PA, Yamagata K, Hanley AJ, Zinman B, Harris SB, Barrett PH, Hegele RA: HNF-Ialpha G3I9S, a transactivation-deficient mutant, is associated with altered dynamics of diabetes onset in an Oji-Cree community. Proc Natl Acad Sci USA 2002, 99:46|4-46I9.

46. Hegele RA: Premature atherosclerosis associated with monogenic insulin resistance. Circulation 200I, 103:2225-2229.

47. Abu-Amero KK, Al-Boudari OM, Mohamed GH, Dzimiri N: T null and $M$ null genotypes of the glutathione $S$-transferase gene are risk factor for CAD independent of smoking. BMC Med Genet 2006, 7:38.

48. Manfredi S, Federici C, Picano E, Botto N, Rizza A, Andreassi MG: GSTMI, GSTTI and CYPIAI detoxification gene polymorphisms and susceptibility to smoking-related coronary artery disease: a caseonly study. Mutat Res 2007, 621:106-I I2. 
49. Lahoz C, Schaefer EJ, Cupples LA, Wilson PW, Levy D, Osgood D, Parpos S, Pedro-Botet J, Daly JA, Ordovas JM: Apolipoprotein E genotype and cardiovascular disease in the Framingham Heart Study. Atherosclerosis 2001, 154:529-537.

50. Talmud PJ, Stephens JW, Hawe E, Demissie S, Cupples LA, Hurel SJ, Humphries SE, Ordovas JM: The significant increase in cardiovascular disease risk in APOEepsilon4 carriers is evident only in men who smoke: potential relationship between reduced antioxidant status and ApoE4. Ann Hum Genet 2005, 69:613-622.

5I. Brull DJ, Dhamrait S, Moulding R, Rumley A, Lowe GD, World MJ, Humphries SE, Montgomery HE: The effect of fibrinogen genotype on fibrinogen levels after strenuous physical exercise. Thromb Haemost 2002, 87:37-4I.

52. Humphries SE, Henry JA, Montgomery HE: Gene-environment interaction in the determination of levels of haemostatic variables involved in thrombosis and fibrinolysis. Blood Coagul Fibrinolysis 1999, I0(Suppl I):SI7-2I.

53. Bereczky Z, Balogh E, Katona E, Czuriga I, Karpati L, Shemirani AH, Edes I, Muszbek L: Decreased factor XIII levels in factor XIII A subunit Leu34 homozygous patients with coronary artery disease. Thromb Res 2008, 121:469-476.

54. Bereczky Z, Balogh E, Katona E, Pocsai Z, Czuriga I, Szeles G, Karpati L, Adany R, Edes I, Muszbek L: Modulation of the risk of coronary sclerosis/myocardial infarction by the interaction between factor XIII subunit A Val34Leu polymorphism and fibrinogen concentration in the high risk Hungarian population. Thromb Res 2007, I20:567-573.

55. Corella D, Guillen M, Saiz C, Portoles O, Sabater A, Folch J, Ordovas JM: Associations of LPL and APOC3 gene polymorphisms on plasma lipids in a Mediterranean population: interaction with tobacco smoking and the APOE locus. J Lipid Res 2002, 43:4I 6-427.

56. Perron P, Brisson D, Santure M, Blackburn P, Bergeron J, Vohl MC, Despres JP, Gaudet D: Apolipoprotein E and lipoprotein lipase gene polymorphisms interaction on the atherogenic combined expression of hypertriglyceridemia and hyperapobetalipoproteinemia phenotypes. J Endocrinol Invest 2007, 30:55 I-557.

57. Hines LM, Stampfer MJ, Ma J, Gaziano JM, Ridker PM, Hankinson SE, Sacks F, Rimm EB, Hunter DJ: Genetic variation in alcohol dehydrogenase and the beneficial effect of moderate alcohol consumption on myocardial infarction. N Engl J Med 200I, 344:549-555.

58. Younis J, Cooper JA, Miller G], Humphries SE, Talmud PJ: Genetic variation in alcohol dehydrogenase IC and the beneficial effect of alcohol intake on coronary heart disease risk in the Second Northwick Park Heart Study. Atherosclerosis 2005, 180:225-232.

59. Tsai CT, Hwang JJ, Ritchie MD, Moore JH, Chiang FT, Lai LP, Hsu $K L$, Tseng CD, Lin JL, Tseng YZ: Renin-angiotensin system gene polymorphisms and coronary artery disease in a large angiographic cohort: detection of high order gene-gene interaction. Atherosclerosis 2007, 195:172-180.

60. Kardia SL, Bielak LF, Lange LA, Cheverud JM, Boerwinkle E, Turner ST, Sheedy PF, 2nd, Peyser PA: Epistatic effects between two genes in the renin-angiotensin system and systolic blood pressure and coronary artery calcification. Med Sci Monit 2006, I2:CR I 50-CR I 58. 